Anna Skolimowska

St. Majewski Spółka Akcyjna S.K.A.

\title{
Formy przekazu baśni w epoce wtórnej oralności - między archaiczną a współczesną recepcją niewspółczesnych dzieł literatury dla dzieci
}

\author{
Był, jest i zawsze będzie pewien raz... \\ (Pierre Péju, Dziewczynka w baśnio- \\ wym lesie)
}

Zrodzona z mitu prabaśń powstała w kręgu kultury oralnej i pokonała długą drogę, nim pogrążyła się we „wtórnej oralności”, którą Walter Jackson Ong definiuje jako zasadniczy wyróżnik dzisiejszej kultury wysokiej technologii ${ }^{1}$. Spowita pomroką dziejów baśń „stanowi niewyczerpane źródło znaczeń i obrazów. Ludowa i anonimowa, przygarnięta następnie przez literaturę, wyznaczyła trwałe punkty odniesienia i wzorce, choć zawsze potrafiła siać niepokój”' ${ }^{2}$ W warunkach prymitywnej kultury oralnej (Claude Lévi-Strauss sugeruje, by określenie „prymitywny” zastąpić sformułowaniem „bez pisma”3) baśnie opowiadane były w celu zaspokajania oczekiwań ludzi dorosłych, a za pierwotnego odbiorcę tych niezwykłych opowieści zwykło się uznawać nie dziecko, lecz człowieka „żyjącego w obrębie wyobrażeń magicznych, dla którego świat baśni jawił się jako swoista reprezentacja jego własnych pragnień, oczekiwań i lęków, mająca związek z życiowym doświadczeniem osoby dorosłej”" . Dzisiejsza baśń stanowi integralny element literatury dziecięcej, zdefiniowanej przez Jerzego Cieślikowskiego jako wszystko to, „co dzieci wzięły od dorosłych, co dla nich dorośli

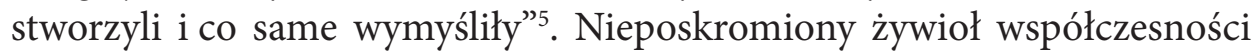
nacechowany wszechobecnymi znamionami dominacji mediów elektro-

\footnotetext{
${ }^{1}$ W. J. Ong, Oralność i piśmienność. Słowo poddane technologii, Warszawa 2011, s. 42.

${ }^{2}$ P. Péju, Dziewczynka w baśniowym lesie. O poetykę baśni: w odpowiedzi na interpretacje psychoanalityczne i formalistyczne, tłum. M. Pluta, Warszawa 2008, s. 7.

${ }^{3}$ W. J. Ong, Oralność i piśmienność..., s. 255.

${ }^{4}$ J. Ługowska, Baśń jako wprowadzenie do myślenia aksjologicznego, [w:] G. Leszczyński (red.), Kulturowe konteksty baśni, t. II, Poznań 2005, s. 27.

${ }^{5} \mathrm{D}$. Wojciechowska, Po co komu smutne baśnie - o problemach dziecięcej tanatologii, [w:] J. Ługowska (red.), Baśnie nasze wspótczesne, Wrocław 2005, s. 201.
} 
nicznych zmienia jednak interpretacyjny kontekst omawianych utworów i przekształca oczekiwania ich odbiorców. Zaznaczająca się w rezultacie cywilizacyjnych metamorfoz przewaga słowa pisanego nad mówionym, a następnie prymat obrazu nad słowem pisanym, głęboko przeobraziły naturę gatunku, zaś współczesność przyniosła zburzenie dotychczasowego porządku opartego na tradycji, a tym samym sprawiła, że odwieczna rola baśni stała się nazbyt staroświecka: „Druk zastąpił dominację słyszenia - dominacją widzenia, którą zapoczątkowało pismo, ale wsparcie samego pisma nie wystarczyło do jej rozkwitu"6.

\section{Z baśnią przez wieki - gatunkowe peregrynacje}

Uniwersalny i ponadczasowy charakter baśni sprawia, że odnajdujemy ją w różnych postaciach w każdej niemal kulturze, jednakowoż bardzo rzadko traktowana jest dziś jako pochodna mitu, zwykło się ją bowiem postrzegać jako opartą na zmyśleniu i nieprawdzie narrację przeznaczoną dla dzieci, pozwalającą zaznawać przeżyć niezwykłych i zdolną pokonywać monotonię powszedniości. Prastara, lecz stale ewoluująca baśń wpisana jest w niezwykle rozległy kontekst przeobrażeń cywilizacyjnych, bowiem specyfika obszarów i czasu powstawania odciskają, w naturalny sposób, piętno na treściach i na formie gatunku. Bez względu na źródło pochodzenia wszystkie te sięgające czasów „przedszkola ludzkości” opowieści przesiąknięte są elementami tradycji, zwyczajami, normami moralnymi, pejzażem i kolorytem miejsc, w których je opowiedziano i usłyszano.

Na pogańskie i przedpogańskie tło europejskiej baśni - które w czasach Apulejusza korzystało ze stylistycznych ozdobników i onomastyki zaczerpniętej z mitologii - nałożyły się w kolejnych wiekach prawo, moralność feudalno-rycerska oraz chrześcijańskie wpływy, a w pewnym momencie także pochodząca ze Wschodu fala motywów i metaforyki, jaka rozprzestrzeniła się w okresie największego zagrożenia ze strony Turków

Przekazywane pierwotnie ustnie, a następnie rozpowszechniane za pośrednictwem słowa pisanego, tradycyjne baśnie - to teksty o ludowym genotypie, utkane $\mathrm{z}$ wyobrażeniowej materii, powstałe $\mathrm{w}$ rezultacie podglądania otaczającej rzeczywistości. Doniosły wkład w rozwój europejskiej ars fabulae wniosła włoska XVI-wieczna tradycja literacka. Pierwszym znanym z nazwiska autorem zbioru baśni jest Giovanni Francesco Straparo-

\footnotetext{
${ }^{6}$ W. J. Ong, Oralność i piśmienność..., s. 186.

${ }^{7}$ I. Calvino, Baśnie włoskie zaczerpnięte z przekazów tradycji ludowej i opowiedziane na nowo, przeł. S. Kasprzysiak i in., Warszawa 2002, s. 29.
} 
la di Caravaggio. Dwutomowe dzieło Straparoli zawierające kilkadziesiąt opowiadań i 21 baśni opatrzone zostało tytułem Le Piacevoli Notti i wydane w Wenecji w latach pięćdziesiątych XVI stulecia, niebawem też przetłumaczono je na francuski. W zbiorze Straparoli nowela, zajmująca dotąd uprzywilejowaną literacką pozycję, ustępuje miejsca swej starszej, wywodzącej się z ludu "siostrze” - baśni, którą przepełnia obfitość magicznych i nadprzyrodzonych wątków, gotyckich i orientalnych motywów rodem z obrazów Vittore Carpaccia oraz język wzorowany na twórczości Giovanniego Boccaccia. W XVII wieku w Neapolu następca Straparoli, Giambattista Basile, tworzy przeniknięty barokowo-dialektalną stylistyką zbiór baśni zatytułowany pierwotnie Lo cunto de li cunti, trattenemiento de li peccerille: „To historie niczym z sennego koszmaru ogarniętego obsesją grozy neapolitańskiego Szekspira, w których roi się od czarownic i potworów, a także makabrycznych i wyszukanych wizji, łączących w sobie to, co wysokie, z tym, co niskie i plugawe"s. Opublikowane dopiero w 1634 roku, utwory Basilego opatrzone zostały ostatecznie tytułem Il Pentamerone. Dzieło zostało przełożone z dialektu neapolitańskiego na język włoski przez Benedetta Crocego, a ostatnia wersja tłumaczenia pochodzi z 1925 roku. Istotny wpływ na dzieje prezentowanego gatunku wywarła w kolejnym stuleciu dramatyczna twórczość Carla Gozziego, który wprowadził baśń na deski teatru, a swe wpisane na trwałe w wenecką panoramę utwory przyoblekł w konwencję komedii dell'arte.

Jednakże złote czasy baśni mają swój początek na wersalskim dworze Ludwika XIV, u schyłku wielkiego wieku XVII, kiedy to Charles Perrault ustalił reguły gatunku, a utrwalone przezeń w formie pisanej ludowe opowieści, przekazywane dotąd z ust do ust, zyskały nową, wyszukaną postać. Nastała wówczas euforyczna, acz przejściowa, moda na baśnie, której ostateczny kres położył kartezjański racjonalizm.

Jutrzenka ugruntowanej rehabilitacji gatunku zajaśniała wraz z nastaniem modernizmu. W zachodnioeuropejskiej kulturze wysoką i trwałą pozycję baśniom nadał romantyzm, tymczasem w Polsce przekonanie o negatywnym oddziaływaniu utworów o ludowej proweniencji utrzymywało się jeszcze przez całą pierwszą połowę XIX wieku. Polska folklorystyka romantyczna zrodziła, co prawda, pierwsze zbiory bajek ludowych, a tradycje literatury oświeceniowej nawiązywały do cenionych wcześniej baśni François Fénelona i Leprince de Beaumont, jednak „upadek Reczpospoli-

\footnotetext{
${ }^{8}$ Ibidem, s. 8.
} 
tej szlacheckiej sprawił, że wzory francuskiej baśni literackiej uformowane w dobie ancien régime’u okazały się anachroniczne, a biorąc pod uwagę bardziej frywolne owoce baśniomanii, wręcz niemoralne"9.

Wraz z początkiem XIX wieku w Niemczech bracia Jacob i Wilhelm Grimm wskrzesili krwawe, posępne, ziejące ponadczasowym średniowieczem opowieści ludowe i zamieścili je w zbiorze Baśnie dla dzieci i dla domu, który ukazał się w grudniu 1812 roku. Aczkolwiek pierwsze wydanie wzbudziło niesmak, gwałtowną krytykę i liczne kontrowersje, to z czasem $\mathrm{z}$ upodobaniem zaczęto sięgać po przepełnione grozą baśnie.

\section{Od słowa do słowa... - od pierwotnej do wtórnej oralności}

Kultura oralna towarzyszyła społecznościom ludzkim od zarania, piśmienność zaś pojawiła się znacznie później i istniała jedynie w obrębie określonych grup. Homo sapiens zamieszkuje Ziemię od blisko 50000 lat, tymczasem ślady pierwszego pisma, które rozwinęło się wśród Sumerów w Mezopotamii, pochodzą sprzed około 6000 lat. Walter Jackson Ong podkreśla, że spośród wielu tysięcy języków, jakimi w ciągu wieków posługiwała się ludzkość, tylko niewiele ponad 100 związało się z pismem. Większość nie została nigdy zapisana: „Spośród około 3000 języków, jakie są dzisiaj w użyciu, tylko 78 ma literaturę"10. „Technologia elektroniczna” wprowadza nas obecnie w erę wtórnej oralności, którą w przeciwieństwie do pierwotnej, poprzedziło pismo i druk. Zarówno pierwotna jak i wtórna oralność wykazują wiele analogii, cechuje je: „mistyka uczestnictwa, karmienie poczucia wspólnoty, skupienie na chwili bieżącej, a nawet używanie formuł"11.

Dzisiejsza baśń, nierozerwalnie spojona z kulturą pisma i druku, różni się znacznie od swych gatunkowych antenatów, w których tworzeniu posiłkowano się jedynie słowem mówionym:

W tradycyjnym społeczeństwie baśń była najczęściej kojarzona z wieczornicą, w której brali udział wszyscy członkowie wiejskiej społeczności, niezależnie od wieku, dla przyjemności lub angażując się we wspólne działanie. Latami powtarzano te same baśnie, tymi samymi słowami. Śladu zniecierpliwienia, śladu zniechęcenia wobec ,już słyszanego", wręcz przeciwnie! ${ }^{12}$.

Baśń wyrosła w kręgu pierwotnych społeczności, zrosła się z nimi silnie za przyczyną słowa mówionego i przeobraziła w integralny element ich kul-

\footnotetext{
${ }^{9}$ R. Waksmund, Od literatury dla dzieci do literatury dziecięcej, Wrocław 2000, s. 162.

${ }^{10}$ W. J. Ong, Oralność i piśmienność..., s. 37.

${ }^{11}$ Ibidem, s. 205.

${ }^{12}$ P. Péju, Dziewczynka w baśniowym lesie..., s. 8.
} 
tury. Na bajarzach ciążyło jarzmo odwiecznej tradycji ludowej i jej niepisane prawo, wedle którego bez krzty inwencji należało powtarzać przywoływane po stokroć motywy, choć sądzić można, że potrafili oni „swym gawędom nadawać kształt jędrnej narracji i niezależnie od tego, ile razy opowiadali tę samą bajkę, ich opowieść zawsze utrzymywana była w tej samej temperaturze żywego uczuciowego zaangażowania"13. Pierwotne baśnie krążyły w obrębie określonych wspólnot dopuszczających, zdaniem włoskiego kulturoznawcy Vittoria Santolego, pewną treściową różnorodność, która dokonywała się poprzez „selekcję niektórych motywów, upodobanie do wybranych szczegółów, tworzenie pewnych typów postaci, nastrój osnuwający opowieść, cechy charakterystyczne stylu, odzwierciedlające określoną specyfikę kulturową"14. Baśniowe słowo mówione zostało poddane zabiegom pisemnego unieśmiertelnienia i zdołało zamknąć efemeryczny, typowy dla opowiadania dźwięk w widzialnej przestrzeni:

Prapoczątkiem pisania jest sytuacja komunikacyjna właściwa „bajaniu”: relacja matka (niania, piastunka, babka) - dziecko. Chodzi właśnie o bajanie, jest ono "twórcze”, otwarte na swobodę kreacji, w przeciwieństwie do „odtwórczego" mówienia wierszy czy śpiewania, ich istotą jest bowiem powtarzalność stałych sekwencji ${ }^{15}$.

Baśń podlega zarówno przemianom formalnym jak i przeistoczeniom percepcyjnym, ponieważ zmieniają się sposoby postrzegania rzeczywistości. Niezależnie od form przekazu, tradycyjne baśniowe treści są niezwykle pomierne, w obszernym repertuarze ich schematów mieści się bezlitosny podział na władców i poddanych, którzy w jednakiej mierze podlegają igraszkom przewrotnego losu. Pojawia się w nich prześladowanie niewinnego bohatera i powzięty przezeń odwet na złym, zdradzający dychotomię ludzkiej natury. Kwitnie uczucie, które mija, nim zdąży się go w pełni zaznać, a piękno skrywa się pod maską szpetoty. Jest uleganie czarom, złym urokom, wpływom nieznanych mocy. Protagonista podejmuje nadludzkie wysiłki w imię wypełnienia elementarnych powinności, zaś wierność zobowiązaniom i czystość serca okazują się fundamentalnymi cnotami zdolnymi nieść ocalenie i zwycięstwo.

Baśń literacka, nawiązując do uniwersalnych motywów i toposów charakterystycznych dla formy prostej gatunku, w znacznej mierze utrwala ludowe w swej

\footnotetext{
${ }^{13}$ J. Cieślikowski, Wielka zabawa, Wrocław 1985, s. 255.

${ }^{14}$ I. Calvino, Baśnie włoskie..., s. 16.

${ }^{15}$ G. Leszczyński, Baśń: rytuał przejścia (rite de passage), [w:] idem (red.), Kulturowe konteksty baśni, s. 46.
} 
genezie wyobrażenia o dobru i sprawiedliwości, stabilizując wzorzec opowiadania z obowiązkowym happy-endem, w którym bohater pozytywny wspierany przez donatora i mający do dyspozycji niezwykłych pomocników oraz magiczne przedmioty jest w stanie podołać najtrudniejszym wyzwaniom, okazując się - w finale opowieści - godnym ręki królewny i połowy królestwa ${ }^{16}$.

Przywołane powyżej treści stanowią źródło głębokich przeżyć odbiorczych, niezależnie od tego, czy przekazywane są w formie oralnej czy kaligraficznej. Dziś cudowne historie bywają z rzadka opowiadane. Słuchają ich głównie kilkulatki, które nie posiadły jeszcze sztuki samodzielnego składania liter. Małe dzieci, które już zupełnie dobrze radzą sobie ze słowem drukowanym, przedkładają słuchanie i oglądanie baśni nad samodzielne czytanie, tymczasem pamiętać należy, że edukacja baśniowa stanowiąca swoistą introdukcję dziecka w świat haute littérature otwiera przed małym czytelnikiem podwoje świata wielkiej literatury, stanowiąc zarazem podstawowy etap inicjacji literackiej. Baśń „jest czymś więcej niż rozrywką [...], jest bowiem wstępem do literatury. Pozwólmy więc dziecku rozkoszować się baśnią, póki tego chce, pozwólmy mu spokojnie z niej wyrosnąć. W odpowiednim czasie bez przymusu porzuci świat baśni i sięgnie po książkę"16.

Emocje odbiorcze, jakie rodzą się w rezultacie obcowania $\mathrm{z}$ baśnią są odwrotnie proporcjonalne do wieku dziecka. Fundament baśniowej edukacji, obejmującej pierwotnie sfery emocji, a wtórnie kategorie intelektualne, stanowi specyficzny język symboli, którego znajomość posiąść powinien każdy z nas, a głównym elementem składni tego symbolicznego kodu jest nie słowo, lecz obraz, który „wart jest tysiąca słów”. Ten pełen ukrytych i niedopowiedzianych treści język baśni wymaga nie dosłownego, lecz obrazowo-symbolicznego odczytywania:

Uwzględniając wielorakie funkcje baśni jako lektury dla dzieci, należy temu gatunkowi wyznaczyć szczególne miejsce nie tylko w procesie wychowania ze względu na wyrazistą aksjologię, ale też w propedeutyce edukacji literackiej. W kontakcie z baśnią dziecko od najmłodszych lat wchodzi w krąg znaków, kodów i symboli, które przygotowują je do późniejszej percepcji różnorodnych tekstów kultury ${ }^{17}$.

Zdaniem wybitnego francuskiego „filozofa dzieciństwa” Pierre’a Péju, baśń zaspokaja potrzebę fantazjowania - „ulegania w wyobraźni tysiącom

\footnotetext{
${ }^{16}$ R. Waksmund, Od literatury dla dzieci..., s. 180.

${ }^{17}$ Z. Adamczykowa, Literatura dziecięca, funkcje - kategorie - gatunki, Warszawa 2004, s. 180.
} 
pokus mentalnego pragnienia tysięcy rzeczy"18, a słowo pisane jako jedyne umożliwia niekończącą się eksplorację baśniowego lasu.

„Czytanie tekstu oznacza przekształcenie go w dźwięk, głośny lub wyobrażalny w czytaniu powolnym, sylaba za sylabą, a niedokładny w czytaniu błyskawicznym, właściwym kulturze wysokiej technologii”19 - głośne czytanie baśni dziecku daje czytającemu możliwość silniejszego uwypuklenia sensu tekstu poprzez stosowne zaznaczanie pauz i akcentów logicznych. Zwalnianie lub przyspieszanie lektury stwarza sposobność uwydatniania różnic tempa akcji, zaś ściszanie bądź nasilanie głosu służy stosownemu oddawaniu nastroju utworu. Czytający dziecku dorosły, kreśląc przed małym odbiorcą baśniowe pejzaże, uciekać się nadto może do różnorodnych - niepopularnych wśród wielu z nas - quasi aktorskich środków pozawerbalnych, uwypuklając tym samym wartości emocjonalne i artystyczne tekstu (mina, grymas, poza ciała, naśladowanie odgłosów...). Na jakość przeżywania baśni przez dziecko, podobnie jak i każdej innej formy narracji, ma wpływ sytuacja odbioru, czyli okoliczności towarzyszące lekturze, zaś czytanie ma swój pozaksiążkowy ciąg dalszy - emocjonalne zaangażowanie $\mathrm{w}$ świat baśniowych przygód wyzwala postawy wykonawcze, wyrażające naturalną ekspresję dziecka (zabawy, rysunki, gry oparte na kanwie usłyszanej baśni...). Starsze dzieci, w wieku 9-11 lat, zachęcane przez nauczycieli, mogą podejmować próby tworzenia własnych baśni, korzystając z przyswojonej wcześniej matrycy strukturalnej tekstu. Nieopisaną radością napawa widok małego dziecka, które trwa w oczekiwaniu na czytanie, trzymając książeczkę pełną cudownych przygód tak mocno i kurczowo, aż bieleją mu opuszki palców małych, pulchnych rąk, a baśniowy strach przeplatany szczęściem zaznawanym podczas lektury, maluje na krągłej buzi rumieniec - dziecko pragnie słuchać.

Słuchanie - to niejako pierwszy krok do samodzielnego obcowania z dziełem literackim. W akcie lektury czytelnik utożsamia się z bohaterami, określa własne emocje i doznania, znajduje odpowiedzi na pytania, które zadaje sobie oraz światu, a na podstawie wiedzy i doświadczenia, w jakie jest wyposażony, interpretuje - na swoją modłę - to, co czyta. Jako że każdy tekst ma wsparcie pozatekstowe, to ,interpretacja tekstu - zdaniem Rolanda Barthes'a - musi wyjść poza tekst, by dotrzeć do czytelnika; tekst nie ma znaczenia, dopóki ktoś go nie czyta; aby miał sens, musi zostać zinterpre-

\footnotetext{
${ }^{18}$ P. Péju, Dziewczynka w baśniowym lesie..., s. 15.

${ }^{19}$ W. J. Ong, Oralność i piśmienność..., s. 38.
} 
towany, a więc powiązany ze światem czytelnika”20. Obcujący z baśnią czytelnik przechodzi swoisty obrzęd wtajemniczenia, a księga przejmuje rolę, jaka w dawnym społeczeństwie przypisana była szamanowi.

\section{Rzecz o wyobraźni}

Tradycyjne utwory baśniowe przenika pulsujący zmiennym rytmem nastrój, zaś pozornie spłaszczony, dwuwymiarowy i rzeźbiony w płytkim reliefie gatunkowego schematu świat $\mathrm{w}$ istocie nasycony jest intensywnym życiem, które silnie oddziałuje na sferę emocjonalną dziecka i na jego wyobraźnię. John Ronald Reuel Tolkien wyodrębnia cztery cechy dystynktywne prawdziwych baśni: odkrywanie siebie, ucieczkę od rzeczywistości, pocieszenie oraz fantazję, rozumianą jako połączenie realnej i nierealnej rzeczywistości, niezbędne do stworzenia wewnętrznego obrazu świata, który pozwala uwolnić się od determinujących wydarzeń.

W baśniowej tkance ciasno splatają się wątki nierealne i rzeczywiste - iluzja, ułuda, „czary-mary” i nieprawda wiodą krętą, często wybrukowaną niebezpieczeństwami i nieoczekiwanymi zwrotami akcji, drogą ku odkrywaniu uniwersalnych prawd: „Każda rzeczywistość potrzebuje wsparcia płynącego ze strony jakiejś nierzeczywistości; każda nierzeczywistość jest odpowiedzią na pytanie jakiejś rzeczywistości" ${ }^{21}$. Włodzimierz Propp, twórca Morfologii bajki, który otworzył nowy rozdział w historii analizy gatun$\mathrm{ku}$, opracowując klucz metodologiczny pomocny w badaniach porównawczych nad baśniami pochodzącymi z różnych stron świata, dowodzi, że oś kompozycyjną bajki magicznej „wyznaczają dwa królestwa”- jedno: realne, ziemskie i drugie: magiczne, bajkowe ${ }^{22}$. Urealnienie fantastyki dokonuje się wówczas, gdy czasoprzestrzeń baśniowa nabiera cech rzeczywistości w procesie czytelniczej konkretyzacji: „Fantastyka powoduje odrealnienie czasoprzestrzeni, a przez to rozszerzenie przedstawionego świata o wymiar intencjonalnej rzeczywistości wytworzonej przez bajkę magiczną, rządzącej się niepodważalnymi zasadami moralnego ładu i sprawiedliwości"23.

Jeśli przyjmiemy, że w fantazjowaniu wyobrażenie jest tym, czym zabawka w zabawie, wyobraźnię traktować winniśmy jako zinternalizowaną formę zabawy. Zdaniem Umberta Eco, fantazja i fikcja stwarzają możliwość

\footnotetext{
${ }^{20}$ Ibidem, s. 239

${ }^{21}$ R. Kubicki, Koniec pewnego świata, czyli o baśni opowiadanej w chwilach tryumfu i zgonu, [w:] G. Leszczyński (red.), Kulturowe konteksty baśni..., s. 16.

${ }^{22}$ W. Propp, Nie tylko bajka, przeł. D. Ulicka, Warszawa 2000, s. 115.

${ }^{23}$ J. Ługowska, Baśnie nasze wspótczesne, Wrocław 2005, s. 246.
} 
wykorzystywania umiejętności obserwacji świata, wskrzeszania przeszłości i projektowania przyszłości. Dzięki nim dokonuje się dziecięce oswajanie dorosłości, zaś „my, dorośli ćwiczymy umiejętność organizowania naszego minionego i obecnego doświadczenia”24. Kontakt z baśnią ubogaca wyobraźnię, a rozwój sfery wyobrażeń warunkują doświadczenia dziecka oraz stymulacja ze strony otoczenia. Adresatem tekstu, który otwiera magiczna formuła „za siedmioma górami”, „musi być dziecko, albo przynajmniej osoba gotowa przyjąć rzeczy sprzeciwiające się zdrowemu rozsądkowi i racjonalnemu myśleniu" ${ }^{25}$. W odbiorze baśni dziecko chłonie fikcję w naturalny sposób, zaś dorosły udaje.

„Najbardziej oczywistym tekstualnym (to znaczy wewnętrznym) sygnałem fikcyjności jest wprowadzająca formuła - dawno, dawno temu..." ${ }^{26}$. Wkraczając w wymiar baśni, dziecko wie, że nic nikomu nie może się stać, a każdy jęk bólu i uroniona łza są tylko na niby i przybliżają nas do zwieńczonego szczęściem i dobrem zakończenia. Baśń wyzwala pragnienie obcowania z niezwykłościami, jakie wyczarowuje nieokiełznana magia, a fantazja sprawia, że linie demarkacyjne oddzielające Realne od Nierzeczywistego zacierają się. Nie można oprzeć się wrażeniu, że wartką akcję baśni napędzają siły tkwiące poza opisywanym światem i że trwale wpisany jest w nią „cud”. Dzięki bogactwu wyobraźni mali odbiorcy wykraczają poza granice dziecięcego mikroświata i powracają z baśniowych wędrówek „za siedem gór i siedem rzek" uzbrojeni w nową wrażliwość. Opuszczając bezkresne przestrzenie onirycznej imaginosfery, biorą z wolna w posiadanie namacalną rzeczywistość. Wycieczki poza horyzonty rzeczywistości pozwalają lepiej przystosować się do rygorystycznych norm narzucanych później w dorosłym życiu. W baśniową topografię trwale wpisany jest szlak wędrówki, usłany gęsto przygodami, którym podąża główny bohater, a w ślad za nim - odbiorca, mały homo viator. Nawet książę, który postanawia odnaleźć księżniczkę wyrusza w drogę „o własnych siłach, na własnych nogach. W butach wędrowca. [...] wystarczy iść do przodu, rozwijać się, szukać. Być wędrowcem. I wtedy buty, w których idziemy, okazują się zaczarowane, złote"27.

\footnotetext{
${ }^{24}$ U. Eco, Sześć przechadzek po lesie fikcji, tłum. J. Jarniewicz, Kraków 2007, s. 162.

${ }^{25} \mathrm{Ibidem}$, s. 15.

${ }^{26}$ Ibidem, s. 148.

${ }^{27}$ W. Eichelberger, A. Suchowierska, Bajka to życie, albo z jakiej jesteś bajki, Warszawa 2010, s. 262 .
} 


\section{Wątek autobiograficzny}

W ostatnim czasie moja 12-letnia córka i o rok od niej młodszy syn, wzięli udział w ogólnoszkolnym konkursie wiedzy dotyczącym Tolkienowskiej powieści Hobbit, czyli tam i z powrotem. Przygotowania do konkursowych zmagań zwieńczonych, nota bene, laurami trwały od tygodni. Dzieci, chcąc zgłębić treść powieści, której dotychczas nie znały, sięgnęły najpierw po jej tradycyjne, książkowe wydanie, a w kolejnej fazie utrwalania detali akcji w sukurs przyszedł im wytwór literatury audialnej - audiobook:

Podstawowa różnica między literaturą tradycyjną a literaturą audialną polega na posługiwaniu się odmiennymi rodzajami języka naturalnego: w pierwszym wypadku jest to język pisany, w drugim - [...] pośredni język mówiony. Literatura oparta na piśmie i druku korzysta ze znaków abstrakcyjnych, bezgłośnych słów oderwanych od swoich wyrazicieli i od konkretnych sytuacji wypowiedzenia. Natomiast literatura audialna oparta na mowie oraz gamie dźwięków naturalnych i konkretnych, znaczeniowo związana jest ściśle z wypowiadającymi słowa osoba$\mathrm{mi}, \mathrm{z}$ ich głosem i osobowością ${ }^{28}$.

Przez wiele godzin, wieczór w wieczór, przed snem dzieci wsłuchiwały się w „miękki” - jak to określały - głos lektora. Ciemność, która je wtedy spowijała i wieczorny spokój z przygodami Bilbo Bagginsa w tle, sprzyjały budowaniu własnego obrazu Śródziemia i zamieszkujących je postaci, a słuchanie baśni stało się wieczornym rytuałem.

Wreszcie przyszła kolej na film... Dzieci obejrzały zekranizowaną wersję powieści - Hobbit: Niezwykła podróż, która pod koniec zeszłego roku weszła na ekrany polskich kin. Film, który zyskał szerokie grono zwolenników i tyluż przeciwników, obejrzały z dziecięcym, naiwnym zachwytem, którego wagę po wielokroć podkreślał Gaston Bachelard w swej Poetyce marzenia: „Dzieciństwo, suma rzeczy najmniej znaczących w ludzkim bycie, ma własne znaczenie fenomenologiczne, znaczenie fenomenologiczne czyste, ponieważ wywodzi się spod znaku zachwycenia"29.

Wartka akcja i wizja narzucona przez reżysera - Petera Jacksona zdołały uwieść i zachwycić dzieci, choć wyrażane później recenzje - abstrahując od formułowanych w prosty sposób uwag na temat nieprzystawalności fabuły filmowej do treści powieści - brzmiały: „Mój Bilbo był ładniejszy”, „Norka hobbicka, którą ja wymyśliłem, była bardziej przytulna”, „Inaczej wyobrażałam sobie krasnoludy”, „Trolle są przecież inne”...

\footnotetext{
${ }^{28}$ M. Hopfinger, Literatura i media po 1989 roku, Warszawa 2010, s. 31.

${ }^{29}$ G. Bachelard, Poetyka marzenia, tłum. L. Brogowski, Gdańsk 1998, s. 147.
} 
Współczesność sprawiła, że baśń, by móc przetrwać, winna być nie tylko zapisana, lecz dodatkowo zobrazowana. Ciekawe, jak pomysł przyobleczenia w obraz swej powieści przyjąłby sam Tolkien, który był przecież zagorzałym przeciwnikiem wszelkich „zabiegów reanimacyjnych”, jakim poddaje się baśń w celu jej uatrakcyjnienia:

Ilustracje do baśni, choć mogą być bardzo dobre, nie przydają baśniom wartości. [...] Jeśli mówi się w danej historii: „Wspiął się na wzgórze i ujrzał stamtąd rzekę płynącą w dolinie”, ilustrator może mniej lub bardziej adekwatnie przedstawić, jak sam wyobraża sobie ten widok, ale każdy, kto słyszy te słowa, ma w tym momencie własny obraz, na który składają się wszystkie wzgórza, rzeki i doliny, jakie kiedykolwiek widział, przede wszystkim jednak obraz ten przedstawia Wzgórze, Rzekę i Dolinę, stanowiące dla niego niegdyś pierwsze konkretyzacje tych słów ${ }^{30}$.

Dziś dzieci pytane o sposób odbioru, który preferują, odpowiadają zgodnie wespół - „wieczorne słuchanie” (spełniać jednak ono musi pewne warunki, gdyż oczekiwania względem lektora są sprecyzowane - „musi mieć pluszowy głos, nie chropowaty, nie za stary i nie piskliwy...”). Podążając labiryntem ukrytych w dźwiękach treści, dzieci mogą z zamkniętymi oczyma praktykować magiczne myślenie, wprawiając w ruch mechanizmy wyobraźni „bez pęt”, wystarczy, że tuż obok, u wezgłowia znajduje się odtwarzacz CD... Szkoda, że nie Babcia... Cóż, takie czasy...

\section{Kres baśniowej wędrówki, czyli ku szczęśliwemu zakończeniu}

Wydawać by się mogło, że tradycyjna baśń jako forma archaiczna i anachroniczna, nie nadąży za dzisiejszą, galopującą rzeczywistością, zważywszy, że następstwem inwazji kultury masowej i jej audiowizualnego wymiaru jest przekład treści pisanych na uniwersalny język obrazów: „Obecnie jest zbyt wiele obrazów, nieco wcześniej było zbyt wiele słów”31. Ale to już inna bajka.

Życzylibyśmy sobie, aby baśnie, bez względu na formę ich przekazu, były dla dziecka przedmiotem kontemplacji estetycznej oraz indywidualnego i intymnego poznawania poprzez przeżywanie. Elementarnym zadaniem tych „cudownych i pożytecznych” opowieści ma być dostarczanie wzruszeń, zaspokajanie oczekiwań ludycznych dziecka oraz stymulowanie jego wyobraźni, choć „dziś obcujemy z różnymi adaptacjami, z których

\footnotetext{
${ }^{30}$ Cyt. za: B. Bettelheim, Cudowne i pożyteczne. O znaczeniach i wartościach baśni, t. I, tłum. D. Danek, Warszawa 1985, s. 127.

${ }^{31}$ R. Kubicki, Koniec pewnego świata..., s. 20.
} 
każda jest czymś ontologicznie skończonym. Nie ma możliwości kreowania świata, modyfikowania go - ewentualna potrzeba kreatywności spełnia się jedynie w interpretacji”" ${ }^{2}$.

Analiza kondycji dzisiejszej baśni pozwala jednak mieć nadzieję, że przyszłość stanie się sprzymierzeńcem gatunku i zaowocuje zaskakującymi strukturalnymi przemianami i niespodziewanymi treściowymi metamorfozami, aczkolwiek rodzić się może obawa, że powita zostanie nowa antropologia dzieciństwa, a wysoce dziś ceniona literatura dziecięca przeistoczy się w zjawisko artystycznie anachroniczne i kulturowo skarłowaciałe.

Imperatywem współczesnego człowieka, nieco na przekór przyobleczonej w wielorakość obrazów rzeczywistości, powinno stać się podsycanie w sobie i w dzieciach pragnienia opowiadania i chęci słuchania, by nie spełniło się proroctwo Pierre’a Péju zwiastujące unicestwienie tych dwóch, coraz bardziej archaicznych dziś umiejętności:

Kiedy stawiamy pierwsze kroki w trzecie tysiąclecie, powinniśmy dobrze ocenić znaczenie tej gigantycznej machiny narracyjnej, uwikłanej w planetarną teraźniejszość, w której obrazy nabrzmiewają, a potem pękają jak bańki mydlane. Istnieje bowiem niebezpieczeństwo, ze te ulotne, płoche historie, które owa machina bez przerwy produkuje, zdławią do postaci wspomnienia to, czym była niegdyś czynność opowiadania ${ }^{33}$.

Pomimo tego, że zdolność opowiadania $\mathrm{z}$ wolna zanika, a obraz zaznacza swój prymat nad słowem, możemy być spokojni o przyszłość baśni, gdyż „był, jest i zawsze będzie pewien raz...”34, a żądne cudowności „dzieciństwo trwa całe życie" 35 .

\section{Bibliografia}

Adamczykowa Z., Literatura dziecięca, funkcje - kategorie - gatunki, Warszawa 2004.

Bachelard G., Poetyka marzenia, tłum. L. Brogowski, Gdańsk 1998.

Bettelheim B., Cudowne i pożyteczne. O znaczeniach i wartościach baśni, przeł. D. Danek, t. I-II, Warszawa 1985.

\footnotetext{
${ }^{32}$ Ibidem, s. 22.

${ }^{33}$ P. Péju, Dziewczynka w baśniowym lesie..., s. 11.

${ }^{34}$ Ibidem, s. 16.

${ }^{35}$ G. Bachelard, Poetyka marzenia..., s. 30.
} 
Calvino I., Baśnie włoskie zaczerpnięte z przekazów tradycji ludowej i opowiedziane na nowo, przeł. S. Kasprzysiak, J. Popiel, K. Skórska, A. Wasilewska, M. Woźniak, M. Wyrembelski, t. I, Warszawa 2002.

Calvino I., Fiabe italiane, Mediolan 1993.

Cieślikowski J., Wielka zabawa, Wrocław 1985.

Eco U., Sześć przechadzek po lesie fikcji, tłum. J. Jarniewicz, Kraków 2007.

Eco U., Sei passeggiate nei boschi narrativi, Mediolan 2000.

Eichelberger W., Suchowierska A., Bajka to życie, albo z jakiej jesteś bajki, Warszawa 2010.

Hopfinger M., Literatura i media po 1989 roku, Warszawa 2010.

Kubicki R., Koniec pewnego świata, czyli o baśni opowiadanej w chwilach tryumfu i zgonu, [w:] G. Leszczyński (red.), Kulturowe konteksty baśni, t. II, Poznań 2005.

Leszczyński G., Baśń: rytuał przejścia (rite de passage), [w:] G. Leszczyński (red.), Kulturowe konteksty baśni, t. II, Poznań 2005.

Ługowska J., Baśń jako wprowadzenie do myślenia aksjologicznego, [w:] G. Leszczyński (red.), Kulturowe konteksty baśni, t. II, Poznań 2005.

Ong W. J., Oralność i piśmienność. Słowo poddane technologii, Warszawa 2011.

Péju P., Dziewczynka w baśniowym lesie. O poetykę baśni: w odpowiedzi na interpretacje psychoanalityczne i formalistyczne, przeł. M. Pluta, Warszawa 2008.

Propp W., Nie tylko bajka, przeł. D. Ulicka, Warszawa 2000.

Waksmund R., Od literatury dla dzieci do literatury dziecięcej, Wrocław 2000.

Wojciechowska D., Po co komu smutne baśnie - o problemach dziecięcej tanatologii, [w:] J. Ługowska (red.), Baśnie nasze współczesne, Wrocław 2005. 